\title{
The Social Realist Stories of Putu Shanty as Historical Record
}

\section{Balinese Culture and Indonesian National Politics in the 1950 s}

\author{
INyoman Wijaya | ORCID: 0000-0002-3976-5129 \\ Universitas Udayana, Denpasar, Indonesia \\ iwijayastsp@yahoo.co.id \\ I Nyoman Darma Putra | ORCID: 0000-0002-2852-7918 \\ Universitas Udayana, Denpasar, Indonesia \\ idarmaputra@yahoo.com
}

Adrian Vickers | ORCID: 0000-0002-1215-6462

University of Sydney, Sydney, NSW, Australia

adrian.vickers@sydney.edu.au

\begin{abstract}
Putu Shanty was one of Bali's leading intellectuals in the middle of the twentieth century, but he has been effaced from official publications identifying cultural leaders of the island. His short stories, written in a social realist style, were intended as interventions that would influence the course of history but are also a valuable record of historical discourse. 'Anti-feudalism' was a central discursive concern of Shanty's, and while it was shared on a national level with other political leaders and writings, its implications on Bali were highly specific, involving local social contestation and attempts to redefine religion. The role of intellectuals such as Shanty demonstrates that there are significant differences between discourses of the 1950s and the early-twenty-firstcentury constitution of 'tradition'.
\end{abstract}

\section{Keywords}

Bali - discourse - literature - realism - LEKRA

(C) I NYOMAN WIJAYA, I NYOMAN DARMA PUTRA AND ADRIAN VICKERS, 
The August 2019 premiere of the long-awaited feature film Bumi manusia (This earth of mankind) did not produce the shock that was expected. Readers of Pramoedya Ananta Toer's novel, from which the screen adaptation is derived, were expecting to see his leftist politics projected onto the screen. The film included a simplified version of the original's anti-colonialism, but in a melodramatic style that ignored the book's complex analysis of class relations (compare with Fitriyani 2019). The period in which Pramoedya's discursive horizons were formed, the 1940s to the middle of the 1960s, was one in which complex class relations could be conceptualized. Everyone was talking about class, especially in terms of 'feudalism'. By the early-twenty-first century, such a conceptualization has become impossible. Understanding the local politics around this major discursive break helps us understand the effectiveness of the underlying national politics which saw the wiping out of the Left in the anti-communist killings of 1965 .

The literary writings of Balinese writer Putu Shanty (1924, Jombang-1965, Singaraja) illustrate the importance of such discourses of class, especially the local factors that shaped participation in national discourse. That participation provides an important way to re-conceptualize Balinese history in terms of how literary works provide insights into perceptions of society. Shanty was a member of the Lembaga Kebudajaan Rakjat (LE KRA, the People's Culture Institute), known for its links to the Partai Komunis Indonesia (PKI, the Communist Party of Indonesia), in which Pramoedya was a prominent figure. Shanty took on LEKRA's agenda of radical change. This was an agenda which coincided with that of the previous generation of Balinese cultural activists. Shanty's writings show a basic tension amongst Balinese intellectuals between preserving distinctly Balinese aspects of their religion and modernizing — reforming —in order to create a more egalitarian society. Shanty's vision of social justice is one that was lost when he died in 1965, as one of the 500,0oo-to-one-million killed in the anti-communist purges that began that year. Such progressive vision of the 'modern' runs counter to Bali's cultural tourism or touristic culture (Picard 1996).

Putu Shanty's writings, especially in their concern with discourses of 'feudalism', illustrate a significant epistemological shift in Bali since the 196os. In the 1950s, Bali was closely linked to politics centred on Jakarta (Robinson 1995). As we will show, this connection was also a cultural one, in which Bali occupied a potentially complex position as both object and agent of discourse. Bali's cur- 
rent position in Indonesian discursive formations is quite different to that of the 195os, since it is tied up with the topic of 'cultural tourism' as dependent on 'tradition', a term that includes 'religion' (Picard 1996, 2011; Hauser-Schäublin 2011). This process of reifying tradition as a category is based on a fixed version of 'culture' (Wijaya 2010). The emphasis is on a static and harmonious society, not one divided by class and the struggles between conservative and progressive forces going on in the 1950s and 196os. The negativity of 'feudalism' has been replaced with a positive framing of 'tradition'.

The 195os are a key period for understanding both how Indonesia came into being, and for examining the structural differences between the early independence period and the seemingly monolithic New Order period of 1967-1998 (Vickers 2001, 2008). In the 1980s and 199os, the hitherto undocumented history of Bali in the 195 os began to be mapped out, beginning with an overview by Vickers (1989) and an early study by I Gusti Ngurah Bagus on political contestation (1991). This history was most fully developed in Geoffrey Robinson's study of the political economy of Bali and its relationship to centralizing tendencies in Indonesian state structures (1995). Subsequent to this new interest in recent history, Nyoman Darma Putra, Nyoman Wijaya, and Maya S.T. Liem produced the first studies on literature of the period (Putra 2000, 2003, 2011; Wijaya 2000; Liem 2003, 2012). Wijaya's was the first study to directly connect the content of literature from the 1950s with social change.

Bali-based studies show the importance of connecting the province to politics and the arts on the national level. Taking a national perspective in their contributions to a groundbreaking collection of articles on pre-New Order culture, Heirs to world culture, Els Bogaerts (2012) and Michael Bodden (2012) refer to Shanty's work as examples of short stories and plays that were part of a larger national movement, and one with international implications. Likewise, Liem (2000:158) lists him among those Balinese writers who published in national magazines such as Budaya, Merdeka, Mimbar Indonesia, and Siasat, along with his associates Made Kirtya, Gde Mangku, and Nyoman S. Pendit. Like the other artists discussed in Heirs to world culture, these Balinese intellectuals connected with the outside world, and, although coming from a 'region' outside of the national centre, Java, were involved in Indonesia's cultural debates.

The position of Bali in national culture mirrored Bali's role in national politics. In a contribution to the book mentioned above (Putra 2012) and an earlier essay (Putra 2003), Darma Putra sought to explore how 'national culture' was understood locally in Indonesia, especially by looking at the Bali chapter of the Lembaga Kebudayaan Nasional (LKN, National Culture Institution), an organization affiliated with the Partai Nasional Indonesia (PNI, the Indonesian Nationalist Party). Darma Putra explored two main areas: the develop- 
ment of the local branch of the LKN through its relationship with the national headquarters of the LKN and with other Balinese cultural institutions; and how national, political activities affected LKN Bali's cultural activities between 1959 and 1965 . He argued that the LKN enriched local cultural activities, with members enthusiastically using various forms of traditional and modern arts to express their nationalistic fervour (Putra 2012). What remains to be explored is how discourses in literary works were part of historical events, particularly in the wider context of political contestation, in other parties and cultural bodies opposed to the PNI and the LKN. Building on Wijaya's earlier use of short stories to understand social interaction in 195os' Denpasar, this article seeks to deepen Indonesian historiography by looking at literature as historical discourse, focusing on a leading writer and his literary output.

\section{$2 \quad$ P. Shanty}

Not much is known about P. Shanty (the form of his name he preferred, but it is also spelt 'Santi'), despite the fact that his writings show him to have been a leading intellectual of post-independence Bali. The way he signed his name at the time tells us that he was a modernizer: he only used the initial of his birth-order name, Putu, preferring the personal name hitherto played down in polite usage. His parents were Ketut Mandra and Luh Gelgel, who made a living through farming and petty trading respectively in the area of Dlod Peken, part of the city of Singaraja in North Bali. Mandra took a job as a mechanic and driver for Dutch officials, moving the family to Jombang in East Java, where Shanty was born in 1924. It is interesting to speculate that in Java, the young Shanty may have been one of the few people with direct knowledge of the colonial rulers, who were otherwise distant from the population. It seems likely that the family moved back to Singaraja during the Japanese period, or possibly even before then. In Singaraja, Santy would have experienced a milieu in which emerging intellectuals-including some of his family members-were using the new form of print magazines and newspapers to produce literature that engaged with social change. These periodicals included Surya Kanta, Bali Adnjana, Bawa Negara and Djatajoe. The Japanese period saw the encouragement of cultural activities such as theatre, which possibly influenced Shanty to write plays (see Putra 2008b).

Between 1952 and 1954, Shanty was editor-in-chief of the biweekly magazine Bhakti (Devotion), published in Singaraja with journalists in several cities including Mataram, Lombok, and Jakarta. Singaraja was the centre of intellectual life in Bali at the time. The city had been the capital of the Dutch 
administrative region of Bali and Lombok since the nineteenth century, a role it continued in the early period after independence, when it was capital of the province of the Lesser Sundas. In 1957, the capital shifted to Denpasar, as Bali became a separate province. Denpasar had its own modern magazine, Damai (Peace), led by another important intellectual and freedom fighter during the Indonesian Revolution of 1945 to 1949, I Gusti Bagus Sugriwa.

During the Japanese occupation, Singaraja became a centre for education. Prior to that time, Balinese students had had to travel to Malang in East Java for more advanced education. The presence of the Japanese opened up possibilities for the Balinese to build up local education, which provided a basis for the post-independence development of new schools. Those who contributed to this development in Singaraja included Gedong Bagoes Oka and Yasmin Oka, who were at the forefront of advancing the position of women, and the Dutch socialist volunteer Jef Last. Singaraja was also the home of the Kirtya Liefrinck-van der Tuuk, a major library and intellectual centre, later known as the Gedong Kirtya. Shanty's uncle, Wayan Bhadra, was a major intellectual figure from the 1920 s to the 1950s who worked in the Gedong Kirtya, wrote for various magazines, and had close links to Western scholars resident in Bali. Through him, Shanty met Last and the Dutch scholar-administrator Roelof Goris, the latter also contributing articles to Bhakti (Putra 2002:64).

In Singaraja, Shanty linked up with other Balinese intellectuals, most importantly his contemporary, the writer Nyoman S. Pendit (1927-2013), who had come from Tabanan in West Bali to Singaraja for his education; and the younger poet Putu Oka Sukanta (b. 1939), who had been born in Singaraja. All three travelled from Singaraja in North Bali to the new national capital of Jakarta during the 195os. Pendit was mainly based in Jakarta in this period, where he made significant contributions to Indonesia's tourist and hotel industry, as well as producing a stream of writings on history, philosophy, and religion. Pendit and Shanty, together with K. Surawan, K. Malaya, and N. Wisade, established their magazine Bhakti in Singaraja in 1952. Other editors included Ni Kt. Sarini, at a time when women were still rarely found in editorial roles (see Pendit 1954).

There is no clear information on Shanty's other travels to Java, but in Bhakti, Shanty wrote an account of his trip to Jakarta with Pendit and Wisade in 1954. They stayed in Rawamangun, which was a focal point for the approximately 250 Balinese living in the capital, and where a Balinese temple was later built. In the capital they met with most of the leading literary figures of the time: H.B. Jassin, Sitor Situmorang, Achdiat K. Mihardja, Utuy T. Sontani, and Idrus, although Pramoedya Ananta Toer, whom they were keen to meet, was in the 
Netherlands at the time of the visit (P.S.H. [Shanty] 1954). It seems that by 1953 Shanty had already been in correspondence with these and other national figures, and had travelled outside of Bali on a number of occasions. Pramoedya's writings were also published in Bhakti. The illustrators of Shanty's stories in Mimbar Indonesia also include leading young, modern artists of the time: the Sumatrans Nashar and Tino S., and Solihin from Kalimantan.

As well as travelling to other parts of Indonesia, young Balinese travelled overseas. Later in 1954, Pendit went to India to study at Rabindranath Tagore's Visva Bharati University at Santiniketan. During the mid 1950s, Shanty travelled on cultural missions to Poland and China, naming two of his children in memory of those trips: his wife, Ketut Sasih, gave birth to their fourth child when Shanty was on a cultural tour in Warsaw with the well-known gamelan group of Sawan, Buleleng, so this daughter was called Ni Luh Warsawanti (combining 'Warsaw' with 'Sawan'); his youngest child, Made Santi Suta, was given the birth name of Kecim because he was born on Shanty's return from China.

\section{Putu Shanty's Writings}

Shanty was active in a variety of publishing spheres. His editorship of Bhakti included the writing of reports, reviews, and essays. In both his own magazine and in others, he published poetry and dramatic works as well as many short stories. Not all of these have survived; for example, we only have two dramas: one from 1953, 'Bangkerut' (Bankrupt) (Shanty 1953a), and a drama from 1965, 'Banting stir' (Turn the wheel hard [to the left]!), the title of which was inspired by the rhetoric of President Sukarno (Bodden 2012:459). Shanty's literary output, particularly his short stories, is most significant because it presents us with nuanced and highly developed ideas that illustrate society at the time.

Shanty's short stories from the 195os were written in a realist style popularized in Indonesia by authors such as Pramoedya. One of the national magazines to which Shanty contributed, the weekly Mimbar Indonesia, presented itself as 'giving content to independence' through supporting social welfare and development, showing how literature was seen by the editors and contributors as having a role not just in developing national culture but also in enhancing social and economic progress (Bogaerts 2012:231). Realism was the main vehicle for achieving this literary aim, and Shanty's stories from Mimbar Indonesia'Ajam djago' (1950a), 'Padi' (195ob), 'Peti maut' (1950c), 'Es lilin' (1951), 'Kekalahan jang ke-empat' (1952a), and 'Réntenir' (1954a)—specifically display fea- 
tures of social realism. ${ }^{1}$ Some, if not all of these stories were also published in Shanty's Bhakti magazine, in at least one case subsequent to national publication. ${ }^{2}$

The stories describe social, economic, and physical conditions on Bali, with a focus on economic hardship and injustice. The causes of economic hardship are landlords and moneylenders, whose actions combine with the workings of fate. The injustice is thus related to feudalism. Tradition is a key feature, but in a negative fashion. Tradition is the basis of feudalism and is another element that contributes to hardship. In these stories, the local community is the major site of problems, both in terms of creating and dealing with them.

'Padi' (Rice) is a story about peasants compelled to pay taxes to the government and debts to their banjar (community associations) and others, despite severe water shortages. It focuses on a poor peasant, Pan Karta, who cannot afford to pay the regular levy owed to the irrigation or subak association, the body that controls access to water for wet rice fields. The subak agrees to go to a lake temple to ask the gods there for water, and Pan Karta joins in the trek, on foot. It takes more than two days, but no rain results from the journey. The head of the subak then decides to meet a dukun or balian, a traditional expert in healing and magic, to ask him to make it rain. Members of the subak contribute money for the dukun. Karta has to borrow money for his contribution. It rains a little afterwards, but in an inadequate amount to meet the water needs of all the farmers. Crop failures, one after another, mean that Pan Karta has no choice but to borrow more money from a Chinese moneylender. The story ends with the tragic scene of debt collectors coming to his house to force him to hand over ownership of his rice fields. Pan Karta then leaves, stopping at several cities in his search for a job, but after some time, he is heard of no more.

The main character of 'Es lilin' (Ice candles/Lollies) is a ten-year-old homeless child, Togog (Statue), who must support himself by selling ice lollies at traditional arts performances. When he tires and falls asleep, a thief steals his flask of ice lollies. He is too scared to go back to his employer, a Chinese-Indonesian man. None of those watching the performance shows any concern, but then a compassionate man, Subrata, gives the boy the money to cover the losses. He then invites the boy home to his house, but Togog refuses: "It seems that you prefer to sell ice lollies?", Subrata asks. Togog could only nod in reply' The fixity of social hierarchy was not so easily overcome.

1 Thanks to Maya H.T. Liem Sutedja for copies of these and related materials from Mimbar Indonesia. See also Shanty 1954 b.

2 We have not been able to locate a full set of issues containing the stories, but 'Kekalahan jang ke-empat' and 'Réntenir' both appeared in Bhakti. 
'Ajam djago' (Fighting cock) and 'Réntenir' (a moneylender or 'person of independent means') continue narratives of indebtedness. The former is about a cock-fighter indebted to a Chinese moneylender; in the latter, the Dutchderived term 'Réntenir' covers both 'moneylender' and 'rich landowner. 'Réntenir', set in Singaraja and Banyuning, describes a retired punggawa (district head) of upper-caste (triwangsa origin), I Gusti Gede Kaler. He has five wives, the youngest of which he married after the Revolution, but he has no children. The story emphasizes how much his upper-caste status is reinforced by his role as punggawa, including his use of his status in an exploitative manner to acquire his last wife, a commoner. He had been anti-independence, and now veterans of the Revolution are amongst those indebted to him. One of these is a commoner ( jaba) called I Sukra, who is fired from his civil-service job for punching a superior. After his sacking, Sukra becomes a cock-fighter and falls into debt to Gusti Kaler, who lends money at a rate of $10 \%$ plus collateral. Sukra's collateral is a gold ring valued at the substantial sum of Rupiah 2,00o, despite the fact that he is only borrowing Rp 50o. Unable to repay his debt, Sukra visits Kaler to ask for the ring back so that he can sell it. But Kaler refuses: 'Pay your debt off first, and once that's done, you can get your collateral back.' Sukra accuses Kaler of being a lintah darat or blood sucker (leech on the land). The argument escalates, and Sukra produces his taji or cock-fighting spur. 'Seeing I Sukra pull out the spur, I Gust Gede Kaler rose up from his grand antique chair to flee. But, as quickly as Kaler got up, so quickly did the flashing spur grasped in the hand of Sukra sink into the left breast of the retired punggawa.'

'Peti maut' (Coffin) is about fighting superstition. The story begins by explaining local beliefs: if a coffin in a hospital makes a sound by itself, a patient will soon die. If a taboo mango tree is pruned, when a woman carries off a branch to use as firewood, she will faint and go mad. The protagonist of the story, only referred to in the first person, 'Aku', takes his wife to the hospital to give birth, but in the middle of the night, a coffin makes a knocking sound without anyone hitting it. The protagonist is worried that his wife will die, but she doesn't: she gives birth to a healthy baby. The protagonist reinterprets the superstition to mean that a knock can also signify birth instead of death. As a way of explaining such beliefs, the narrator connects it to the imagination, saying how he enjoyed reading fairy tales and watching fantasy films, from the traditional story of Achmad-Muchamad to the Voleur de Badgad (The thief of Baghdad) and the Arabian nights. Thus, rationality merges with artistry.

The theme of rationality is continued in 'Kekalahanku jang ke-empat' (My fourth defeat), in which Shanty presents an intellectual's resistance to established Balinese religious practices. In this story, the progressive intellectual 
opposed to superstition is at odds with his wife, who is described as holding traditional views and diligently performing Balinese ceremonies. She performs the nelungbulanin ceremonies (celebrating the 105th day since birth) for her first, second, and third child, despite her husband's opposition. In this conflict of modernity versus tradition, the husband seems powerless to intervene in ritual practices, although they reach some sort of compromise at the end of the story.

'Datang angin datanglah petir' (With the wind comes the storm-petir literally means 'thunderbolt') is the only story amongst those discussed here which is set outside of Bali, in Surabaya (Shanty 1955). The title is also notable because of its use of a dramatic, slogan-like phrase, familiar from President Sukarno's speeches. The story is set in Surabaya, a city with which Shanty would have been familiar from his younger days in East Java. The protagonist is a woman called Nyonya Soentari (Tari) Abukarim, who is trapped in a forced marriage with an irresponsible man. The marriage came about because Tari had fallen in love with a Catholic, and her father had made her marry a man she did not love to prevent her marrying outside Islam. Tari visits the house of her aunt and uncle, the Adinatakusumas, during a heavy storm, symbolizing the dark news she brings of her loveless marriage:

I've become a victim of fanaticism! Yes, religious fanaticism! Despite the fact that in this age of independence individuals are supposed to have the opportunity to realize what they really want in their hearts! Free people can choose this or that [political] party! People should be able to follow Islam, Christianity, Buddhism, Hinduism or whatever.

As with 'Kekalahanku jang ke-empat', Shanty challenges the restrictions and burdens of religion, just as 'Peti maut' shows the emptiness of superstition in general. 'Datang angin ...' is the most powerful of these stories, with its depiction of the tragedy of Tari's life through the vivid evocation of the setting and the emotional family interaction.

\section{$4 \quad$ Social Realism and Socialism in Indonesia}

Understanding Shanty's stories as both historically shaped and forming part of history requires an examination of realism in fiction at the time. Such an understanding has been clouded by retrospective views based on Shanty's later politics, particularly the fact that he was an active member of LEKRA, which was best known for its alignment with the PKI. For this membership, Shanty 
and two of his children were killed in the anti-communist purges that swept Bali in December 1965, even though it seems he was not actually a member of the PKI (Putra 2012:336). ${ }^{3}$ His alignment with LEKRA fitted with his use of realism. That same realism allows his short stories to be used to understand the historical experience of the Balinese in the 1950s and early 196os (see White 1993).

The link between individual biographical experience and broader social structures in history is provided by Pierre Bourdieu's concept of habitus: cultural practices which have become 'natural' as an effect structured by one's life-world (Webb, Schirato and Danaher 2002:53). Bourdieu explains the production of a work of art as a dialectical relationship between the structural position or 'post' of an artist and the artist's habitus (Bourdieu 1993:140). This approach of examining individual subjectivity in terms of social structures has proven fertile for understanding individual biographies in general historical terms (see, for instance, Singh 2012; Wijaya 2012), and is even more useful for understanding literature historically.

While the structural elements of Bourdieu's habitus work against an interpretation based on personal agency, this approach can be mediated through a Foucauldian framework in which power is viewed as complex networks of micro-power operations permeating social systems (Foucault 1980:116; 1994). Power not only represses but also creates; in particular, it creates truth through discourse. A historian's task is to recognize the generation of those truths and how they represent different interests (Hunt 1989:9, 34-5). This historicist approach takes account of discourse in relation to artistic production (Ankersmit 1987). Subject positions within power networks provide possibilities of action and the creation of change. These positions are constrained by ideologically defined horizons of expectations, but the contradictions created by ideology in a work of art generate possibilities of historical understanding (Macherey 1978). In post-colonial terms, such contradictions manifest themselves in ambivalence (Budiawan 2010).

Realist short stories in themselves are the product of a trajectory in literary history. Indonesian writers looked to Western examples such as Steinbeck, whose work was translated in Bhakti by Murtini Koriawan, a scholar of English literature married to Nyoman S. Pendit. ${ }^{4}$ Writers of short stories, such as Hemingway, presented the idea of writing as conveying truth in a way that connected with the feelings the writer experienced. They were concerned with the

3 Interview Putra with Ni Ketut Sasih and information from other family members.

4 For example 'Pilon', from John Steinbeck's Tortilla flat (1954); this is actually a chapter from the original book, but it appears as a separate short story in Bhakti. 
power of the ordinary as a form of expression, as Charles May explains for the generic innovations of the twentieth century, exemplified by Chekhov, Hemingway, and Carver (May 1993). May observes how the realist genre was shaped by features such as compression - revealing meaning by omission-and language styles that work through metonymy. These authors also express their inner realities by describing the outer world (May 1993). Srinivasa Iyengar's (1970) conclusions about Indian short stories were similar. The Indian authors he discussed were concerned with everyday life. In his view, although meaning may be universal, it still has a local base. In such short stories, the theme of 'India' offered a middle place, one between the local and the universal. 'India' was evoked through aesthetic means in prose but nonetheless still real. In Shanty's short stories, Bali serves to mediate the local, national, and international in the 1950s. Shanty evokes the ambience and colour of Bali to convey grounded reality connected to broader national concerns.

Shanty was both a bearer and an agent of discourse. As an activist in the arts he shaped the way that Balinese discussed the world, but he did so within horizons that were established by pre-existing forms of writing. He drew on an international form, the short story, but adapted it through local means. He also drew on discourses found in international and Indonesian forms of socialism but localized them within Balinese knowledge forms. His contemporaries in South Bali wrote social realist stories that sought to demystify aspects of urban life by depicting new values and symbols expressing the clash between capitalist culture and the desire for social equality. They did this both by documenting the era and by depicting in moral terms how change was taking place (Wijaya 200o).

Shanty's decision to participate in the magazine Mimbar Indonesia demonstrates that he shared its promotion of intellectual values of liberal equality and cosmopolitan openness. Mimbar Indonesia required its writers to seriously dedicate themselves to the national ideals espoused during the struggle for independence and proclaim themselves to be free of party-political ties (Bogaerts 2012:226). Such participation does not necessarily contradict Shanty's affiliation with LEKRA, given that up until the late 1950s there was quite a lot of fluidity in the political positions and memberships of groups such as this. Nevertheless, in the early 1950s, the vast majority of Indonesian intellectuals - possibly all-followed some form of socialism. Polarization into different factions became a feature of the first part of the following decade. Artists and intellectuals who would later become bitterly divided were still mixing socially and organizationally (Bogaerts 2012).

Across this broad socialist spectrum, social realism was the dominant mode of representation. The liberal, Western-oriented group of writers and painters 
linked to critic H.B. Jassin formed an association called Gelanggang ('Arena'), proclaiming themselves as universal humanists who were 'the true heirs of world culture' (Bogaerts 2012). As Keith Foulcher's analysis of this group's aims shows, they saw literature as having an 'ability to enrich the quality of human experience, both through the aesthetics of form and the perceptions of reality offered by the individual creative experience' (Foulcher 1986:3). The broad aims of Mimbar Indonesia, which included social progress in such areas as equal rights for women, provided an umbrella for the interests of writers from all over the archipelago (Bogaerts 2012:236). In an important article in Mimbar Indonesia of 1950, the leading artist Sudjojono emphasized that art such as his 'combines realism as a form with "real" content, producing art which is intelligible to ordinary people', rather than over-intellectualized formalism (Bogaerts 2012:9). Sudjojono was a founder of LEKRA in 1950. Shanty would definitely have identified with Sudjojono's view, just as his own artistic politics aligned with Sudjojono's realism. ${ }^{5}$ The Gelanggang group and LEKRA agreed about aesthetics and the representation of social realities; rather, a key initial point of difference amongst Indonesian artists in 1950 was whether or not the arts should be developed through links to the Netherlands (Foulcher 1986:167). By 1955, Shanty was publishing in the PKI's newspaper, Harian Rakjat (the People's Daily), signalling a closer alignment with the Left.

\section{5}

\section{Bhakti and Politics in Bali}

The key players of Bhakti focused on two related areas that had been the subject of major cultural conflicts in Bali in the 193os: opposition to caste hierarchy and modernization of religion. Indonesia's first national elections, held in 1955, brought one stage of conflict in Bali to an end, and signalled the beginning of another level of polarization, which increased in the late 1950s. In Bali, the two leading parties were the PNI and the Partai Sosialis Indonesia (PSI, Indonesian Socialist Party). The PKI was still emerging as a political grouping at that time, and there was a variety of other, smaller groupings and bodies. ${ }^{6}$ Like Mimbar Indonesia, Bhakti proclaimed itself as 'non party' on its banner, although its writers espoused different positions on politically contested issues.

At the end of the Revolution, the old aristocracy was strongly identified as

5 Sudjojono had stood in the national elections for the PKI but was expelled from LEKRA and the party in the early 1960s, when he left his wife, Mia Bustam, also a LEKRA artist, for Rose Pandanwangi.

6 For an overview, see Bagus 1991; for more detail, see Robinson 1995:190-200. 
pro-Dutch, particularly through the Paruman Agung, a council of Bali's traditional rulers, which had been established by the Dutch in 1938. This body had been a vehicle for supporting the Dutch during the Revolution in the form of the Dewan Raja-Raja (Council of Kings). Despite some royal Balinese being pro-Republic, there was strong popular identification of the Balinese aristocracy with opposition to independence. The interim ruling body of Bali set up at the time of independence to replace the Council of Kings included Shanty's uncle, Wayan Bhadra. This body consisted of 'moderate nationalists', but there was a significant group of freedom fighters who were not satisfied with the outcome of the struggle and remained in the maquis as semi-bandits. During this period there were frequent political assassinations, most of them revenge killings against pro-Dutch figures, which only stopped after 1955 (Robinson 1995:224-6; Wijaya 2001:39).

In Buleleng, the regency of North Bali, the main political leadership was strongly Republican, with a majority being followers of former guerrilla leaders now in the PNI, with a smaller group of PKI followers. The latter gained $6 \%$ of the vote in the 1955 election and two seats in local government, while the PSI, strong in parts of South Bali, had no significant following in the North (Robinson 1995:196). As Robinson shows, the main focus of politics was not a split between Republicans and 'collaborators' but between different factions and groups within the broader Republican movement (Robinson 1995:195). Bhakti's articles illustrated key issues over which such political differences were played out.

Bhakti includes some directly leftist politics, for example, an article by J. Prajitno on May Day and the international struggle of workers (buruh), including an illustration of Engels. The article exhorts the workers of the Lesser Sundas to know their history and join the celebrations of 1 May 1953 - although sadly the exhortation appeared after May Day had passed (Prajitno 1953). The same issue contained an editorial on the need to support a National Unity Front (Barisan Kesatuan Nasional) to oppose separatism and foreign capital. Below it are two cartoon characters who appear in many issues: a worker holding a hammer and a farmer with a sickle. In the following year the magazine reproduced a detailed explanation of why the PKI was going into elections under the controversial name of 'the PKI and people who are not members of parties' (PKI dan orang tidak berpartai), and thus including non-party members in their list (Darssono 1954). As Putra (2003:29) pointed out, Bhakti denied specific communist associations, in line with its banner proclamation and other statements that it was a magazine for everyone, open to people of all political persuasions.

Despite obvious leftist tendencies, the magazine was also open to collaboration with more conservative nationalists. A Bhakti editorial of 1953, written 
when Shanty was listed as chief editor, argued that the magazine sided with the PNI, as the only party maintaining the national ideology of Pancasila. ${ }^{7}$ Prior to that, Bhakti had published an article by PNI powerbroker Wedastra Sujasa on Hinduism (1952) and a summary of political events by leading PNI local parliamentarian I Gusti Putu Merta (1953). Wedastra was later to emerge as a hardliner on the right wing of the PNI and a major opponent of the PKI (Lane 1972). Nevertheless, in 1954, another editorial of indeterminate authorship, cautioned against 'a certain party based on nationalism', which was campaigning for the forthcoming election by using feudal figures. These feudalists, the editorial warns, had been enlisted to attract the support of rural people, who remain highly feudalistic. These people would only create a 'neo-feudalism' that would cheat the Indonesian people. ${ }^{8}$

Fighting Feudalism

Opposition to feudalism ran deep in the history of Bhakti. The North Balinese group Surya Kanta had been the first modernizers to articulate opposition to the position of the upper castes or triwangsa in the 1920 (Bagus 1969, 1975, 1996; Putra Agung 1974). I Nengah Metra, one of Surya Kanta's leaders, had been exiled by the Dutch to Lombok for marrying a woman of high caste, a demonstration of his active role in such politics. He had been active in setting up political networks through local leadership of the Partai Indonesia Raya (Parindra, Greater Indonesia Party) and as a teacher inspired a generation of nationalists. His Parindra network included Nyoman S. Pendit's father, while Wayan Bhadra was amongst his pupils (Vickers 2000). Bhadra also worked in the Gedong Kirtya with other Surya Kanta leaders such as I Nyoman Kajeng, who became a fighter in the Revolution. The Surya Kanta group continued their work in the magazine Djatajoe, in which Bhadra, using the pseudonym 'Gde Srawana', in 1939 published in serialized form the second modern novel in Balinese, Mlancaran ka Sasak (Srawana 1978). Metra was killed in action whilst fighting against the Dutch in 1946. Pendit documented the importance of Metra and his comrades in his account of the Revolution in Bali (1979).

For the writers of Surya Kanta, feudal caste status should not define who people were. Nengah Metra had argued in 1926 that nobility of character, rather than nobility of birth, should be the only criterion for defining what it was to be Balinese (Vickers 200o:90-1). Twenty-six years later, Shanty and his colleagues

7 'Editorial: Pantjasila', Bhakti 2-27:3 (1953).

8 'Editorial: Awas, neo-feodalisme', Bhakti 2-13:1 (1954). 
were still pursuing this issue. In one of his editorial articles for Bhakti, Shanty argued that the Balinese people were making progress on several fronts in urban areas, but the story was different in rural areas, where the stench of feudalism could still be found. Susanto, then Governor of the Lesser Sunda Islands, had put forward the idea of removing all noble titles, as the nobility were perceived as hindering Bali's development (Sh. [Shanty] 1952:1-2). Shanty believed that implementing such a measure would be impossible; indeed, the government was only capable of replacing noble titles such as Sri Paduka Tuanku Kanjeng, Yang Dipertuan with the more generic bapak-bapak ${ }^{9}$ - gentlemen. ${ }^{10}$

Caste and hierarchy could not be separated. Although the triwangs a looked modern, they remained deeply feudalistic and expected those they regarded as sudra, the lowest caste, to honour them. Shanty argued that this was evident in the deference that members of the sudra caste showed when interacting with members of the triwangsa, as well as villagers' tendency to enquire about caste when making introductions. When members of the sudra caste were interacting with members of other castes, their conversations would be overly polite and respectful; this would not necessarily be true when they dealt with their peers (Sh. 1952:1-2). This humility, according to Shanty, highlighted the continued survival of feudalism, and showed just how difficult it would be for the triwangs a to abandon their feudalistic attitudes.

According to Shanty, progress-defined as the creation of egalitarianismcould not come from above (that is, through gubernatorial policy) but had to come from below, from the people themselves. Members of the sudra caste had to recognize themselves as equal to members of the triwangsa or high castes, since human beings derived value not from their caste but from their conduct and individual personalities. The value of individual human beings comes not from how they treat their members of the same caste but how they treat all human beings (Sh. 1952:1-2).

In Shanty's short story 'Réntenir', I Gusti Gede Kaler is a representative of the kind of feudalist tactics that the Bhakti editorial accuses the PNI of:

'Indeed, the present situation is very bad' (I Gusti Gede Kaler arrogantly interrupted). This has been caused by independence. What did I use to say to the peasants when the kingdom's soldiers were still in power? (Looking about as if afraid of being overheard). 'Do not give food to the activist the 1940s and the 1970s the egalitarian saudara was used to address the second person, but this usage disappeared in favour of the more hierarchical bapak for males. 
youth in the mountains. Because a consequence of independence will be that our country will be ruled by stupid people. They wanted independence. Finally, they are free to do anything. To steal, kill, rob ... argh, keeping up with the current situation makes my head spin. Was I wrong? In such complicated times, who suffers? The people! You! Me! And other people!'

As a noble, he frequently enjoyed the company of local women. He would choose a young virgin from one village one day, then another from another village the next. The Bhakti editorial team drew attention to this issue of the position of women in an article which elaborated on how it intersected with issues of hierarchy (Pembantu Bhakti 1953). In 'Réntenir', sexual exploitation, in the form of coercing a younger woman to be his wife, is shown as being closely related to exploitation of caste position.

More generally, Bhakti presented the view that ordinary people were worthy of respect. In a witty essay, 'Kritikus ${ }^{2}$ and filsuf ${ }^{2}$ dikampung kami' (Critics and philosophers in our village), Shanty (1953b) light-heartedly observed that the critic H.B. Jassin, as well as the philosphers of the western tradition, Socrates, Plato, Jean Paul Sartre, and others joined in local discussions at the local tuak or palm toddy stall owned by Men Liarning in his village. By this, he meant that his fellow villagers, I Banglah, I Pasek, I Mangku, and I Wita, were highly literate, and could hold high philosophical debates and critical analyses in a local setting (Shanty 1953). His point was that elevated intellectual levels were not the exclusive province of metropolitan, let alone European, elites, but could be found on a local level.

Bhakti ceased publication in 1954, but Shanty's opposition to feudalism continued in his writings in the early 196os, as seen in his 1965 essay 'Arahkan udjung pena kedjantung imperialisme feodalisme' (Direct the tips of your pens towards imperialism and feudalism). This article was originally presented at a LEKRA conference in 1962, two years after the PSI was dissolved by President Sukarno and a year after the establishment of LEKRA's Bali chapter (Oka 1962; Putra 2008a:54). This essay indicated that Shanty was affiliated with LEKRA: 'What is LEKRA's attitude towards people's literature? Could people's literature satisfy the people's demand for ongoing revolution and give direction to social progress? Could it become a tool for mobilization in the current age of crime?'

For Shanty, progressive writing was a way to oppose feudalism: 'The feudalists and the neo-feudalists know very well that literature is an effective tool of repression. [...] Feudal writers always depict aristocrats as heroic and great people. And it is impossible for people to challenge them.' As the examples above show, Shanty's counter-tactic was to depict ordinary commoners as 
equally heroic and noble. He described the goal of LEKRA and its writers as establishing this kind of engagement with the people:

LEKRA writers' contribution to Balinese society has indeed not met expectations, as our organization still faces political and material obstacles, as well as imperfect spiritual capabilities. By reaching far and wide, and going into the villages, LEKRA artists can enrich themselves by learning of people's experiences, and using these as material for creating new thoughts.

Shanty's sense of village life continued the theme of ordinary people being respected and valued for who they were. Shanty used the human dimension of realism in his stories to ensure that these were not one-dimensional didactic works, but stories that were capable of communicating the complexity of experience. His characters were rounded and not simply idealized but rather depicted as having doubts and passions.

Shanty's pursuit of topics of social and economic reform as part of his challenge to feudalism led naturally to his views on religion. As with many other intellectuals of the Left in the 1950s, Shanty was concerned by how 'superstition', linked to feudal obligations, meant that the Balinese had to sacrifice money to hold the elaborate rituals imposed by the upper castes. Bhakti published articles about Hindu religion and was a vigorous contributor to debates about the religious changes going on in Bali at the time. Initially, some of these discussions were part of lobbying efforts to have Balinese religion recognized as one of the national religions (Picard 2011).

Most of the articles about religion in Bhakti were concerned with providing a rational explanation of it, based on identification of its essential features. This situated the Bhakti writers within a modern doctrinal turn in Balinese Hinduism. Surya Kanta and its opponent organizations from the 1920 and 193 os were the forerunners of Hindu reformist bodies that emerged at the time of independence. In 1947, the first of these organizations was the council of Brahman high priests, the Paruman Para Pandita (Council of High Priests), a conservative group associated with the pro-Dutch Council of Kings (Picard 2011:487). I Gusti Bagus Sugriwa, the Denpasar-based intellectual and former fighter in the Revolution, was at the forefront of embedding religious reform in Balinese government. Following his lead, two organizations were established 
in Bali, the Klungkung-based Madjelis Hinduisme (Hindu Council), led by I Gusti Anandakusuma, who had close ties to PNI leaders such as Wijakusuma; and the Singaraja-based Panti Agama Hindu-Bali (РAнв, Hindu-Bali Religious Congregation) (Anandakusuma 1966; Picard 2011:488-9). The PAHB's leadership consisted of Surya Kanta and Bhakti writers, including Sugriwa, Bhadra, Nyoman Kajeng, Putu Shanty, and Ketut Kandia. Kandia, a significant contributor to Bhakti, took part in many of the major councils connected with gaining recognition for Balinese Hinduism. Of these councils, the РAн в claimed to have thirty branches with approximately 10,000 members (Kandia 1954; see Shanty $1952 b)$.

I Ketut Kandia had come to prominence as a member of Surya Kanta's successor organization, Bali Dharma Laksana, founded in 1936 to unite the Eka Laksana group in Denpasar with the education group Bali Studiefonds in Singaraja. The initial aim of the group was to promote education and cultural progress more generally. ${ }^{11}$ Amongst his various contributions to the magazine Djatajoe in the 1930s were poems and articles on religious topics, continuing Surya Kanta themes (Kandia 1937). These groups were the basis of the РAнв.

The PAHB's aim was 'deepening and spreading the knowledge of [Balinese Hinduism's] philosophy, simplifying its ceremonies and reducing costs, and getting rid of outdated customs'. This set it at odds with conservative groups, particularly the upper-caste Council of High Priests and its maintenance of caste (Picard 2011:489). Kandia referred to this body as kolot, old-fashioned or passé, the opposite of 'modern' in the discourse of the time (Picard 2011:489; Kandia 1954). The different groups united to meet the national government's requirements for recognition of their religion, and in this they were supported by the Dutch scholar Roelof Goris, who had rejected his country of birth to side with Indonesia during the Revolution (Picard 2011:491). Bhakti published many articles by Bhadra, Goris, and others on the basis of Balinese religion, and particularly advocating reform linked to fundamental doctrines, which emphasized their difference from the kolot groups and provided an egalitarian vision of Balinese religious practice.

Debates on religion were closely linked to literature. Another organization, Wiwada Sastra Sabha (Literary Debate Council), was established in the 195os by Ida Bagus Raka Keniten and I Gusti Bagus Sugriwa to study and discuss religious manuscripts (Picard 2011:49o). While their chief aim was to demonstrate that Balinese religion had 'scriptures' that could meet the standards for national recognition of their religion, the group also drew attention to the importance

11 Patriot 1939; 'Statuten Anggaran Dasar', Djatajoe 1 (25 Nopember):96 (1936). 
of literature in general. Bhadra and the other literary scholars who contributed to Bhakti supported this broad aim, and the magazine included discussions of, and even translations of, works of traditional literature. Making the scriptures, and literature in general, accessible was the basis of the Bhakti editors' and writers' approach to the magazine.

Kandia's contributions to Bhakti were explanations about the general principles of religion, as well as specific article on the aims of the РАнв and its interpretation of Hinduism (Kandia 1953, 1954). In 1954, the Hindu student organization in Jakarta, which was led by Nyoman S. Pendit, protested about the lack of state recognition of their religion, which amongst other things meant that they could not enter their affiliation on official documents, which required identification of 'religion' (P.S.H. 1954:2). Kandia responded to the concerns by discussing the internal and external pressures shaping the РАнв. One of its internal drivers was concern about the perversion of religious practices by Balinese rituals, which had moved away from original practices. He argued that it was important to communicate with the people in the villages to spread this message (Kandia 1954).

Doctrine and practice were closely related. Shanty argued that many youths, especially young women, were reluctant to become involved in ceremonial activities, and as such these ceremonies had to be handled by their in-laws (P.S.H. 1954:2). Kandia answered that young students should not respond to these problems by avoiding religion but rather by finding solutions. Young people living outside Bali needed to gain deeper religious knowledge, which they could spread to their villages of origin both through their words and their practices.

Kandia was also responding to a second pressure: that imposed by other religions. In response to Shanty's message about how students were feeling, Kandia responded that there was no need to convert to Protestantism in search of practical religious practices; practicality could be created in Hinduism. Doing so would enable people to practise their religious teachings without any sense of awkwardness, without any sense of shame. The reference to growing Protestant missionary activity in Bali also implied a second threat, from pan-Islamist groups that wanted to establish an Indonesian State. When the Ministry of Religion initially defined Hinduism not as a 'religion' (agama) but as a 'faith' or 'belief' (kepercayaan), Hindu intellectuals saw the danger and resisted, arguing that Hinduism was equal to Islam and Christianity. It should be noted that the former king of North Bali, famous novelist Anak Agung Panji Tisna, was a prominent convert to Christianity. Tellingly, he had rejected the pro-Dutch position of his fellow kings and was accepted by Bhakti, to the point where they published some of his writings. 
Another Bhakti contributor, Sutrisna Sangging, also saw the pressure of religion as connected to the Cold War. While Indonesia had chosen not to align with either the United States or the Soviet Union, it still faced internal struggles, in which, according to Sangging (1954a, 1954b), communism and religion were the two major forces. Sangging argued that Indonesians had to choose different philosophies and had to resist capitalism. In his view, Pancasila, as the basis of Indonesian nationalism, was important to the nation, since it guaranteed choice of philosophy and religion. Making Islam the national religion was a threat to Pancasila, since it implied the abolition of national boundaries, much as was advocated by the Trotskyite extreme brand of communism (Sangging 1954a). The link between traditional religion and capitalism had already been explained by one Bhakti contributor in terms of the ways that people were pressured to carry out expensive ceremonies by a priesthood that claimed a monopoly on access to knowledge (Paswara 1952).

These same pressures and arguments are played out in Shanty's short story 'Kekalahan jang keempat'. However, the contradiction of simplifying religion without losing its values was something that Shanty could not entirely resolve in his narrative. The main character is a husband who is trying to convince his wife to do away with expensive rituals altogether. The story runs through a range of arguments about what they should do. For the birth of their fourth child, the wife wants to perform the highest level of ceremony, complete with a Brahman high priest or pedanda. The husband argues that this is just a way for the upper caste group to make money, and that they should follow the ideas of the PAHB and reduce the cost of the ceremony.

The husband goes further and takes the position that they should not have any offerings, just kill a pig, buy some palm toddy and hold a party with friends. This provokes the wife into an argument, and in tears, she says to him, 'If so, you'd better be a Protestant. Throw away your religion. Or you could just convert to Islam ....' He counters that he is a 'Vrijdenker' ('free thinker'), who wants to take a neutral position on religion, seeking meaning for himself. She responds that nowadays people seemed to be making up their beliefs however they want. The wife also points out that if they do not hold a ceremony for their baby, they will not be allowed to enter the temple and will be social outcasts.

The story ends in an ambivalent fashion. They cannot afford the ceremony. The wife prepares to sell their clothes, leaving them with the minimum, although she will not sell the children's. The husband hopes his economic and philosophical explanations will win through, and on the day of the ceremony, all their neighbours come to carry out the ceremony for them. A large ceremony with a pedanda is replaced by a ceremony based on the cooperative spirit of 
their village. Thus, Shanty illustrates the points of difference as a kind of debate, rather than taking a simple didactic position.

\section{$8 \quad$ Conclusion}

Putu Shanty's short stories were embedded in the social discourses of Bali, and of Indonesia, in the 195os. Opposition to feudalism and capitalism was assumed as the foundation of social action, but the stories demonstrate the complex realities of North Bali at the time. While advocating for a rationalist society, Shanty and his group still held strongly to the idea that Hinduism was the basis of who they were as Balinese.

The short stories, along with the editorials and other contributions of Bhakti, show us an Indonesia in political turmoil. Different positions inherited from the colonial period and the Revolution were still being played out and continued on into the 196os, when differences hardened. The challenge to feudalism represented a fundamental contest of claims that Balinese tradition constituted social order, in the form of caste and upper-caste domination of religion. In order to address this, those who questioned that order had to oppose the religious basis of caste. It is likely to have been the hardening of these differences, particularly Shanty's opposition to the power of feudal elites like the pedanda and land-owning aristocrats, that led to his murder in 1965 , rather than any philosophical ideas.

As Picard's analysis of New Order tourist discourse on Bali has shown, a reified version of 'culture' was central to the way local and national officials located the island within national culture by the 1970s (1996:178-9). There was no room in this discourse for social conflict, examinations of exploitation, or portrayals of religious difference and inequalities. The New Order's emphasis on stability and 'order' meant that taking these kinds of oppositional stances towards the kolot became impossible after the 196os. The tourist 'brand' of Bali depended on the idea that the island was synonymous with harmony, and that harmony was based on a hierarchical version of the Hindu religion. The obliteration of LEKRA and critical voices was a pre-requisite for establishing a new discourse of a Bali ready to welcome 'cultural tourism'. 


\section{References}

Anandakusuma, I.G.R. (1966). Pergolakan Hindu Dharma II. Denpasar: Pustaka Balimas.

Ankersmit, F.R. (1987). Refleksi tentang sejarah: Pendapat-pendapat modern tentang filsafat sejarah (translated by Dick Hartoko). Jakarta: Gramedia.

Bagus, I Gusti Ngurah (1969). Pertentangan kasta dalam bentuk baru pada masyarakat Bali. Denpasar: Universitas Udayana, Jurusan Antropologi.

Bagus, I Gusti Ngurah (1975). 'Surya Kanta: A Kawangsaan movement of the Jaba caste in Bali', Masyarakat Indonesia 2-2:153-62.

Bagus, I Gusti Ngurah (1991). 'Bali in the 1950s: The role of the Pemuda Pejuang in Balinese political processes', in: Hildred Geertz (ed.), State and society in Bali, pp. 199-212. Leiden: KITLV Press.

Bagus, I Gusti Ngurah (1996). ‘The play “Woman's fidelity”: Literature and caste conflict in Bali', in: A. Vickers (ed.), Being modern in Bali: Image and Change, pp. 92-114. New Haven: Yale University. [Southeast Asia Publications.]

Bodden, Michael (2012). 'Dynamics and tension of LEKRA's modern national theatre, 1959-1965', in: Jennifer Lindsay and Maya H.T. Liem (eds), Heirs to world culture: Being Indonesian, 1950-1965, pp. 453-84. Leiden: KIT LV Press.

Bogaerts, Els (2012). “Wither Indonesian culture”: Rethinking "culture" in Indonesia in a time of decolonization', in: Jennifer Lindsay and Maya H.T. Liem (eds), Heirs to world culture: Being Indonesian, 1950-1965, pp. 223-45. Leiden: KITLV Press.

Bourdieu, Pierre (1993). Sociology in question (translated by Richard Nice). London: Sage.

Budiawan (ed.) (2010). Ambivalensipost-kolonialisme: Membedah musik sampai agama di Indonesia. Yogyakarta: Jalasutra.

Darssono (1953). 'Heboh tentang tanda gambar P.K.I.', Bhakti 3-14/15:3-4.

Fitriyani, Nurbaiti (2019). 'Reaksi interpretatif terhadap teks susastra dan tingkat elaborasi estetika dalam teks sinema: Telaah Bumi manusia sebagai karya adaptasi dari novel ke film', Jurnal Seni Nasional cIKINI 5-2:36-49.

Foucault, Michel (1980). Power/knowledge: Selected interviews and other writings, 19721977 (translated by Colin Gordon). New York: Pantheon Books.

Foucault, Michel (1994). Essential works of Foucault, 1954-1984. New York: The New Press.

Foulcher, Keith (1986). Social commitment in literature and the arts: The Indonesian 'Institute of People's Culture' 1950-1965. Clayton, Vic.: Centre of Southeast Asian Studies, Monash University.

Hauser-Schäublin, Brigitta (2011). 'Spiritualized politics and the trademark of culture: Political actors and their use of adat and agama in post-Suharto Bali', in: Michel Picard and Rémy Madinier (eds), The politics of religion in Indonesia: Syncretism, orthodoxy and religious contention in Java and Bali, pp. 192-213. London: Routledge. 
Hunt, Lynn (ed.) (1989). The new cultural history. Berkeley: University of California Press.

Kandia, I Ketut (1937). 'Ja Dharma', Djatajoe 1-5:186.

Kandia, I Ketut (1953). 'Beberapa tjara merajakan Hari Njepi', Bhakti 2-8:7.

Kandia, I Ketut (1954). 'Sekedar tentang usaha pembinaan: Agama Hindu-Bali', Bhakti $3^{-6: 1-2 .}$

Lane, Max (1972). 'Wedastera Suyasa in Balinese politics, 1962-72: From charismatic politics to socio-educational activities'. [BA (Hons) thesis, Department of Indonesia and Malayan Studies, University of Sydney.]

Liem, Maya H.T. (2000). 'Nyoman Rastha Sindhu: Humanity in Balineseness', in: A. Vickers, I Nyoman Darma Putra and Michele Ford (eds), To change Bali: Essays in honour of I Gusti Ngurah Bagus, pp. 155-83. Denpasar and Wollongong: Bali Post and Institute of Social Change and Critical Inquiry, University of Wollongong.

Liem, Maya H.T. (2003). The turning wheel of time: Modernity and writing identity in Bali, 1900-1970. [PhD thesis, University of Leiden.]

Liem, Maya H.T. (2012). 'A bridge to the outside world: Literary translation in Indonesia, 1950-1965', in: Jennifer Lindsay and Maya H.T. Liem (eds), Heirs to world culture: Being Indonesian, 1950-1965, pp. 163-9o. Leiden: KITLV Press.

Macherey, Pierre (1978). Towards a theory of literary production (translated by Geoffrey Wall). London: Routledge and Kegan Paul.

May, Charles E. (1993). 'Reality in the modern short story', Style 27-3:369-79.

Merta, [I Gusti Putu] (1953). 'Dewan Perwakilan Rakjat Daerah Bali 3 tahun', Bhakti 224:3.

Oka, Putu (1962). 'Orang Bali tentang Bali', Zaman Baru 6-7:10.

Paswara (1952). 'Kapitalis agama punja siasat', Bhakti 1-11:18-21.

Patriot (1939). 'Bekerdja teroes', Djatajoe 4-8:238

Pembantu Bhakti (pseud.) (1953), 'Nasib wanita dalam perkawinan dan feodalisme', Bhakti 2-29:4-5.

Pendit, Nyoman S. (1954). 'Mentjari sigadis hilang', Mimbar Indonesia 8-26:20.

Pendit, Nyoman S. (1979 [1954]). Bali berjuang. Jakarta: Gungung Agung. [Reprinted 2005, Denpasar: Pustaka Larasan and Sarad].

Picard, Michel (1996). Bali: Cultural tourism and touristic culture. Singapore: Archipelago Press.

Picard, Michel (2011). 'Balinese religion in search of recognition: From agama Hindu Bali to agama Hindu (1945-1965)', Bijdragen tot de Taal-, Land- en Volkenkunde 1674:482-510.

Prajitno, J. (1953). '1 Mei dan sedjarahnja (II)', Bhakti 2-14:5-7.

P.S.H. [Shanty] (1954). 'Beberapa tjatatan dari notes jang berantakan (I)', Bhakti 3-1:2-7.

Putra, I Nyoman Darma (200o). 'Bali and modern Indonesian literature: The 1950s', in:

A. Vickers, I Nyoman Darma Putra and Michele Ford (eds), To change Bali: Essays in 
honour of I Gusti Ngurah Bagus, pp. 134-53. Denpasar and Wollongong: Bali Post and Institute of Social Change and Critical Inquiry, University of Wollongong.

Putra, I Nyoman Darma (2003). 'Reflections on literature and politics in Bali: The development of Lekra, 1950-1966', in: Thomas A. Reuter (ed.), Inequality, crisis and social change in Indonesia: The muted worlds of Bali, pp. 55-86. London: Routledge/ Curzon.

Putra, I Nyoman Darma (2008a). Bali dalam kuasa politik. Denpasar: Arti Foundation.

Putra, I Nyoman Darma (2008b). 'Modern performing arts as a reflection of changing Balinese identity', Indonesia and the Malay World 36-104:87-114.

Putra, I Nyoman Darma (2011). A literary mirror: Balinese reflections on modernity and identity in the twentieth century. Leiden: KITLV/Brill.

Putra, I Nyoman Darma (2012). 'Getting organized: Culture and nationalism in Bali 1959-1965', in: Jennifer Lindsay and Maya H.T. Liem (eds), Heirs to world culture, being Indonesian 1950-1965, pp. 315-42. Leiden: KIT LV Press.

Putra Agung, A.A. Gde (1974). 'Perobahan sosial dan pertentangan kasta di Bali Utara, 1924-1928'. [MA thesis, Universitas Gadjah Mada, Yogyakarta].

Robinson, Geoffrey (1995). The dark side of paradise: Political violence in Bali. Ithaca and London: Cornell University Press. [Translated as Sisi gelap Pulau Dewata: Sejarah kekerasan politik; translated by Arif. B. Prasetyo. Yogyakarta: LKiS, 2005.]

Sangging, Sutrisna (1954a). 'Sambutan atas reaksi: R.I. berdasarkan Islam mendjamin kemerdekaan agama dan kebudajaan lainnja?', Bhakti 3-5:5.

Sangging, Sutrisna (1954b). 'Sebuah polemik: Agama dan sekitar pengakuan (II) untuk M. Halus', Bhakti 3-17:1.

Sh., P. [Shanty, P.] (1952). 'Masyarakat Bali sesudah repolusi: Masih ada ketinggalan bekas-bekas masyarakat feodal', Bhakti 1-11:1-2.

Shanty, Putu (1950a). 'Ajam djago', Mimbar Indonesia 4-31:20-3.

Shanty, Putu (195ob). 'Padi', Mimbar Indonesia 4-35:20-1, 27.

Shanty, Putu (1950c). 'Peti maut', Mimbar Indonesia 4-49:20-1, 23-4.

Shanty, Putu (1951). 'Es lilin', Mimbar Indonesia 5-20:20, 25-6.

Shanty, Putu (1952a). 'Kekalahanku jang ke-empat', Mimbar Indonesia 6-28:20-1. [Also published in Bhakti 2-8:8-10 (1953).]

Shanty, Putu (1952b). 'Sebuah persoalan antara: Agama Tirtha dan Hindu-Bali', Siasat 6-264:7.

Shanty, Putu (1953a). 'Bangkerut', Bhakti 2-23:25-32.

Shanty, Putu (1953b). 'Kritikus2 dan filsuf2 dikampung kami', Bhakti 2-25/26:26-3o.

Shanty, Putu (1954a). 'Réntenir', Mimbar Indonesia 8-20/22:27 [Bhakti 3-2:14-20 (1954)].

Shanty, Putu (1954b). 'Berpisah', Bhakti 3-8:6-7.

Shanty, Putu (1955). 'Datang angin datanglah petir', Harian Rakjat, 2 July. [Republished in Rhoma Dwi Yuliantri and Muhidin Dahlan (eds), Laporan dari bawah tanah: 
Sehimpunan cerita pendek Lekra Harian Rakjat 1950-1965, pp. 287-92. Jogjakarta: Mera Kesumba, 2008].

Shanty, Putu (1965). 'Arahkan udjung pena ke djantung imperialisme feodalisme', Zaman Baru 8-9:7-8.

Singh, Sourabh (2012). 'Unraveling the enigma of Indira Gandhi's rise in Indian politics: A woman leader's quest for political legitimacy', Theory and society 41-5:479-504.

Srawana, Gde [I Wayan Bhadra] (1978). Mlancaran ka Sasak. Denpasar: Yayasan Saba Sastra Bali.

Srinivasa Iyengar, K.R. (1970). 'Contemporary Indian short story', Indian Literature 133:36-44.

Steinbeck, John (1954). 'Pilon', translated by Murtini Koriawan, Bhakti 3-10:6-7, 11.

Vickers, Adrian (1989). Bali: A paradise created. Ringwood, Vic.: Penguin.

Vickers, Adrian (2000). 'I Nengah Metra 1902-1946: Thoughts on the biography of a modern Balinese', in: A. Vickers, I Nyoman Darma Putra and Michele Ford (eds), To change Bali: Essays in honour of I Gusti Ngurah Bagus, pp. 89-112. Denpasar and Wollongong: Bali Post and Institute of Social Change and Critical Inquiry, University of Wollongong.

Vickers, Adrian (2001). 'The New Order: Keeping up appearances', in: Grayson Lloyd and Shannon Smith (eds), Indonesia today: Challenges of history, pp. 72-84. Singapore: Institute of Southeast Asian Studies.

Vickers, Adrian (2008). 'Mengapa tahun 1950-an penting bagi Indonesia?', in: Henk Schulte Nordholt, Bambang Purwanto, and Ratna Septari (eds), Perspektif barupenelitian sejarah Indonesia, pp. 67-78. Jakarta: Yayasan Obor Indonesia and Koninklijk Instituut voor Taal, Land en Volkenkunde (KITLV).

Webb, Jen, Tony Schirato and Geoff Danaher (2002). Understanding Bourdieu. London: Sage.

Wedastra Sujasa, (1952). 'Agama Hindu Bali terantjam', Bhakti 1-6:10-11, 19.

White, Rodney M. (1993). 'Teaching history using the short story', The Clearing House 66-5:305-6.

Wijaya, Nyoman (2000). '1950s lifestyles in Denpasar through the eyes of short story writers', in: A. Vickers, I Nyoman Darma Putra and Michele Ford (eds), To change Bali: Essays in honour of I Gusti Ngurah Bagus, pp. 113-51. Denpasar and Wollongong: Bali Post and Institute of Social Change and Critical Inquiry, University of Wollongong. Wijaya, Nyoman (2010). Mencintai diri sendiri: Gerakan Ajeg Bali dalam sejarah kebudayaan Bali 19ro-2007. [PhD thesis, Universitas Gadjah Mada, Yogyakarta.]

Wijaya, Nyoman (2012). Menerobos badai: Biografi intelektual Prof. I Gusti Ngurah Bagus. Denpasar: Pustaka Lasaran. 